Abstracta Iranica Abstracta Iranica

Revue bibliographique pour le domaine irano-aryen

Volume 27 | 2006

Comptes rendus des publications de 2004

\title{
«A Late Safavid Dish: a Cluster of Exotic Trees and Foliage ». Muqarnas, 21, (2004), pp. 121-128.
}

\section{Delphine Miroudot}

\section{(2) OpenEdition}

1 Journals

\section{Édition électronique}

URL : http://journals.openedition.org/abstractairanica/6111

DOI : 10.4000/abstractairanica.6111

ISSN : 1961-960X

Éditeur :

CNRS (UMR 7528 Mondes iraniens et indiens), Éditions de l'IFRI

\section{Édition imprimée}

Date de publication : 15 mai 2006

ISSN : 0240-8910

\section{Référence électronique}

Delphine Miroudot, « «A Late Safavid Dish: a Cluster of Exotic Trees and Foliage ». Muqarnas, 21, (2004), pp. 121-128. », Abstracta Iranica [En ligne], Volume 27 | 2006, document 237, mis en ligne le 02 janvier 2007, consulté le 25 septembre 2020. URL : http://journals.openedition.org/abstractairanica/ 6111 ; DOI : https://doi.org/10.4000/abstractairanica.6111

Ce document a été généré automatiquement le 25 septembre 2020.

Tous droits réservés 


\title{
« A Late Safavid Dish: a Cluster of Exotic Trees and Foliage ". Muqarnas, 21, (2004), pp. 121-128.
}

\author{
Delphine Miroudot
}

Cet article, dédié à Michael Rogers comme l'ensemble du volume, fait l'étude d'un plat safavide inédit conservé dans une collection particulière. L'objet est exceptionnel par ses dimensions ( $49 \mathrm{~cm}$ de diamètre) et très singulier par la densité de sa composition. Ces caractéristiques associées au style, au traitement des motifs, aux teintes (un dégradé de gris) ainsi qu'à la présence d'une base entièrement glaçurée à deux anneaux en ressaut permettent à Y.C. d'attribuer la pièce au tournant des $17^{\mathrm{e}}-18^{\mathrm{e}}$ siècles, avant la chute d'Ispahan en 1722. L'A. prend soin de mettre la pièce en relation avec la production iranienne contemporaine de céramique bleue et blanche qu'elle a largement appréhendée dans un catalogue consacré aux céramiques safavides bleues et blanches du Victoria and Albert Museum (Y. Crowe, Persia and China: Safavid Blue and White Ceramics in the Victoria and Albert Museum, 1501-1738, London, 2002). Elle établit également des liens avec la céramique chinoise des $16^{\mathrm{e}}-17^{\mathrm{e}}$ siècles, mais aussi avec l'art du textile et de la laque du Japon.

\section{INDEX}

Thèmes : 5.1. Monde iranophone 
AUTEURS

DELPHINE MIROUDOT

Musée du Louvre 